\title{
DRIVING FORCES OF THE DEVELOPMENT OF SUBURBAN LANDSCAPE - A CASE STUDY OF THE SULKOV SITE WEST OF PILSEN
}

\author{
Jan Kopp ${ }^{1}$, JindŘich Frajer ${ }^{1}$, Renata Pavelková ${ }^{2}$ \\ ${ }^{1}$ Department of Geography, Faculty of Economics, University of West Bohemia, Pilsen, Czech Republic \\ ${ }^{2}$ Department of Geography, Faculty of Science, Palacký University Olomouc, Czech Republic
}

Manuscript received: June 4, 2015

Revised version: August 15, 2015

Kopp J., Frajer J., Pavelková R., 2014. Driving forces of the development of suburban landscape - a case study of the Sulkov site west of Pilsen. Quaestiones Geographicae 34(3), Bogucki Wydawnictwo Naukowe, Poznań, pp. 51-64. 5 figs, 4 tables. DOI 10.1515/quageo-2015-0028, ISSN 0137-477X.

AвSTRACT: In the study area of the Sulkov site in the western part of the suburban landscape of the city of Pilsen we focus on detailed historical analysis of the development of the landscape, which has undergone significant changes, and thus clearly demonstrates the impact of the driving forces on both the regional and inter-regional levels. The documented historical development of ecotopes proved that the fundamental changes in the use of the natural potential had been determined by social and economical demand. The specific use of each type of ecotopes of the site was then co-decided by the natural potential of the area and the geographic location with good transport connection, i.e. local and regional factors.

KEYWORDS: driving forces, suburban landscape, landscape changes, historical analysis, natural potencial

Address of the corresponding author: Jan Kopp, Department of Geography, Faculty of Economics, University of West Bohemia, Plzeň, Czech Republic; e-mail: kopp@kge.zcu.cz

\section{Introduction and aims}

The current stage of the development of European cultural landscapes is described as postmodern. Antrop (2005) uses the term to describe the development of a cultural landscape since as early as the period after the $2^{\text {nd }}$ World War that is determined by the increasing globalization and in progress in Europe under the influence of cyclic stages of development of settlement systems (Antrop 2004, Ouředníček 2007). The postmodern European landscape at the end of the $20^{\text {th }}$ century is described as a complex mosaic of various landscape types with various levels of anthropogenic transformation (Vos, Meekes 1999). A typical example of dynamic as well as heterogene- ous landscape is a suburban landscape (Antrop, Eetvelde 2000). Thus Forman (1998) emphasizes the necessity of study of the suburban landscape development. The knowledge of the driving forces behind the development of a landscape (see Bürgi et al. 2004, Schneeberger et al. 2007, Markuszewska 2013) as well as its history is prerequisite for designing appropriate strategies for its development and tools for its planning (Marcucci 2000). The knowledge of the historical development of the landscape is the key in this respect (Antrop 2005).

This study focuses on the development of suburban landscape from the $19^{\text {th }}$ century. Extensive and intensive changes have occurred in the Czech country since that time (Vyskočil 2012). The mod- 
el area for a detailed historical landscape-ecological research is the Sulkov site in the west part of the suburban landscape of Pilsen. The site is situated on the edge of the administrative area of the city where the landscape matrix consist of suburban forests. Sulkov is the eastern part of the Líně municipality. The distance from the centre of Pilsen is $7.5 \mathrm{~km}$, the transport distance between the Sulkov site and the city centre is 9.5 $\mathrm{km}$ by road.

Given the population of Pilsen being 168,034 inhabitants to $31^{\text {st }}$ December 2013 and its dominant position in the settlement of the western part of the Czech Republic, Pilsen urban region is currently a region with very clear signs of suburbanization (Kopp et al. 2013). However, the model area demonstrates a residential development which has been influenced by the development of demand for workforce in the bituminous coal mines and kaolin mines in deposits of Pilsen Basin since the first half of the $19^{\text {th }}$ century. The territory most affected by the development of coal and kaolin mining, especially west and north of Pilsen, reached the highest population growth between the second half of the $19^{\text {th }}$ century and the first quarter of the $20^{\text {th }}$ century. However, these sectors of the suburban area presently show a lower level of quality of the environment as well as a lower quality of housing and less attractive for housing development (Kopp et al. 2013).

In the model area, we focus on a historical analysis of the development of the landscape, which has undergone significant changes and thus shows signs of the impact of driving forces on the regional and interregional level. We intend to provide answers to the following questions:

1. Which driving forces determine the development of the landscape?

2. Which factors lead to diversification of use of individual areas in the landscape?

\section{Theoretical analysis}

A suburban landscape is defined as one of the basic landscape types in the classic work of landscape ecology (Forman, Godron 1986). It differs in the gradient of landscape modifications caused by human influence. The landscape modification escalates in the sequence of landscapes: natural - cultivated - farmed - suburban - urban.
Let us not forget that it is not a developmental sequence. A suburban landscape arises only on a certain degree of development of settlement systems thus becoming the youngest type of development, i.e. younger than an urban landscape. A suburban landscape from the view of residential development is formed by the process of suburbanization (Ouředníček 2007, Głębocki, Perdał 2013). The effects of urbanization development of a European landscape are summarised by Antrop (2004), who presented the typology of building expansion of settlements in the landscape.

A suburban landscape is typical for localising new human activities that used to be typical especially for an urban landscape (housing, shopping, storage, production). From the landscape-ecological view, the suburban landscape is distinguished by its relative area of matrix and low connection (Forman, Godron 1986), which is linked with the typical high value of mosaicity of the suburban landscape, i.e. a high number of areas of various types of landscape cover (Antrop, Eetvelde 2000). The intensity of use of areas in a suburban landscape is varied, from the areas that were modified significantly, such as industrial or commercial sites (Spilková, Šefrna 2010) to natural areas, such as remnants of wetlands (Ehrenfeld 2000). The network density of artificial line corridors is on the increase in a suburban landscape (Forman, Godron 1986).

The heterogeneous use of areas of a suburban landscape is the result of its multifunctional use. The growing demand for sustainable management of multifunctional landscapes in Europe is also proved by the creation of specific projects (Landscape Tomorrow: European Research Network for Sustainable Development of Multifunctional Landscapes) and many landscape-ecological studies (Naveh 2001, Valk 2002, Degórski 2003, Heilig 2003).

The extreme intensity of transportation of materials and energy from the surrounding landscape through the suburban landscape to the city results in the origin of a dense network of transport and technical infrastructure. The city's demands on resources of materials, agricultural production, products and energy create pressure on the suburban landscape to ensure natural resources, agricultural production, or products. Thus the suburban landscape faces attempts of a maximum exploitation. Exploitable natural re- 
sources may affect the development of the city. Therefore Forman (1998) emphasises the necessity to protect their quality in the planned development of the suburban landscape.

Natural material and energy flows are channelled, reduced and of ten even interrupted in the suburban landscape (Forman 1998) due to the introduction of prevailing artificial elements in the landscape (housing development, impervious areas, etc.). The outcomes of the urban ecosystem are stored in the suburban landscape in the form of waste. Waste storage results in the origin of little slump areas in the suburban landscape (municipal landfills, disposal sites of construction waste, waste water tanks, etc.).

The mentioned deduction based on the theory of matter and energy flows (Fig. 1) can be summarised in the following features of a suburban landscape:

a) high intensity of matter, products and energy transportation through a suburban landscape,

b) maximum effort to use local natural resources for the city needs,

c) location of city waste storage,

d) possible penetration of the effects of the urban landscape.

Among the driving forces of the landscape development in Europe belong according to Antrop (2005): (1) accessibility of landscape, (2) urbanization, (3) globalization and (4) disasters and calamities. In terms of the suburban landscape, there are two major factors: easy accessibility to the city and suburbanisation as a developmental stage of settlement systems. Globalisation is demonstrated mainly through the influence of foreign investments to constructions of new industrial and commercial areas. This process is called a commercial suburbanisation. Investment intensity depends on the multinational geographic location of the area and the global economic situation as shown the study of foreign investments in the Pilsen agglomeration (Baštová, Dokoupil 2010).

The specific impact of calamities and natural disturbances, e.g. floods or droughts, may be the decisive factor that changes direction of the ongoing tendency of the development (Antrop 2005). The significance of environmental stress factors are emphasised by Balej et al. (2008) in the example of the development of mountainous

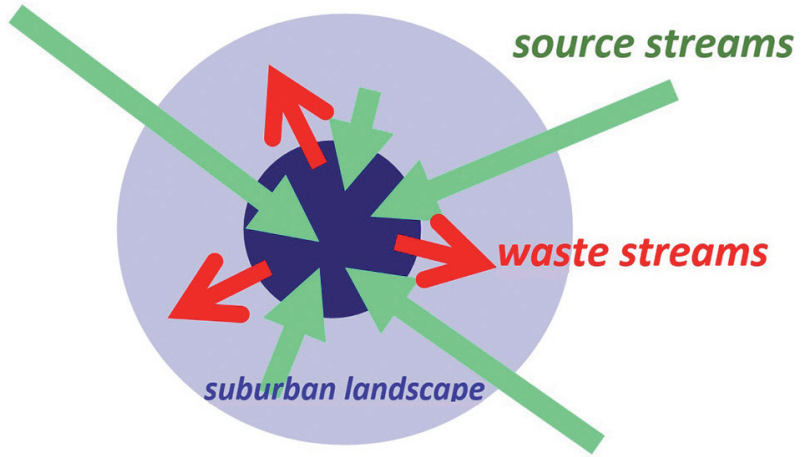

Fig. 1. Suburban landscape in the model of material and energy flow between the city and the surrounding landscape. Processing by Kopp (2012).

and industrial landscape of north-west Bohemia. Their study presents the impacts of individual stages of the development of the society on the landscape exploitation with subsequent impacts on environmental and social quality of the area. Jongman (2002) places economic conditions, technical means, cultural and social aspects as well as planning and policy environment among the key socio-economic factors of the development of the European landscape. Antrop (2005) states that a real landscape development is a certain compromise between the reaction to influential outside factors and planned development of the area. This idea is the core of our focus on the question of whether outside driving forces (often independent and random) are more significant in the development of a suburban landscape or whether it is a planned development determined by the local public administration and local government in the form of strategic plans or land-use plans. In the example of the Belgian landscape Antrop (1998) shows that it is the suburban landscapes which are characterised by chaotic evolution towards entropy.

Due to historical differences in the origin and development of a suburban landscape in our country and in the most economically developed world it is understandable that essential Czech works on the issue of the suburban landscape were scarce in the $20^{\text {th }}$ century (Kovár 1995). In the last fifteen years, we can find new Czech studies on the suburban landscape focused on the impact of suburbanisation (Létal et al. 2001, Mulíček, Olšová 2002, Sýkora 2002, Ouředníček 2007, Spilková, Šefrna 2010). 


\section{Research method}

The aspect of suburban landscape development facilitated the use of research method of historical geography which were next complemented by methods of landscape-ecology research. As is obvious from further studies (see McQuillan 2010), this combination is highly effective in landscape research. The first stage of the research followed from a detailed study of historical resources and information from the archive of research reports of the Czech geological service (Geofond) and of the archive fund of the Chotěšov estate placed in the State Regional Archive in Plasy. Then a detailed field survey of the Sulkov site followed. The results were further complemented by previous eco-hydrological research of a wider area of the Luční Brook Basin (Kopp 2004, Kopp 2012). The studied area was selected as a model site with the most significant changes in the development of the landscape in the western part of the suburban landscape of Pilsen. We proceeded in detail to compare the development in five specific sites of the area (Fig. 2 map).

Such ecotopes were selected which had been flooded by the waters of the ponds Sulkov and Lažikov in the first half of the $19^{\text {th }}$ century (i.e. they had the same "starting" position). The use of the studied locations further developed in different ways. A different intensity of landscape exploitation can be observed in the selected ecotopes. While in the location of ecotope 2 the use has changed five times, the ecotope 4 has not been used by human activities since the Lažikov pond drainage in the middle of the $19^{\text {th }}$ century. An important feature of the selected ecotopes is the fact that they are part of the same area. The distance between the outer ecotopes of the area ( 1 and 4) is 1600 metres. Regarding the criterion of observing the development of a suburban landscape it is then possible to suppose the same geographic location of all observed sites, i.e. for example the almost identical accessibility, the distance to Pilsen, the same position in the settlement system, etc. Obviously, they differ in detail, e.g. in the mesoclimatic position of the ecotopes, the relation to the main hydrographic axis of the area (the distance from the Luční Pond) or probably also the position of recoverable reserves of hard coal under the surface.
The documentation of the ecotope development was elaborated in the form of a chronological table with a detailed commentary of the environmental history of ecotopes. In order to quantify the development of the ecotopes, we chose a method based on Hessian scoring methodology of ecological value of habitats. This method, which has been developed since the 1980s in Hesse, reflects 8 habitat characteristics (maturity, nature, structure diversity, species diversity, habitat rarity, species rarity, vulnerability, and endangerment (Seják 2005, Seják et al. 2011). A table evaluation of a detailed list of habitats is the base of calculating the characteristic number of the points. The point value is used for a referential monetary evaluation of ecological functions as one of the methods of evaluating the indirect utility value of a territory (Bräuer 2003, Seják et al. 2011). The monetary evaluation is determined applying the method of renewal costs. This method of evaluation has been experimentally introduced in the conditions of the Czech Republic. A spreadsheet followed from the development of the method of evaluation allowing the conversion of the point valued to the habitat category mapped in the European project Natura 2000 (Chytrý et al. 2001, Seják 2005). And it was the inclusion in the habitat categories of the Natura 2000 system that we applied in our research. It seems a problem to determine in reverse the habitat categories in the development from the beginning of the $19^{\text {th }}$ century. Despite that, we presume that it is possible to prove the inclusion into the nearest habitat category on the basis of historical resources respecting the fact that it is essential to determine the ecological value and not the habitat category form the view of botany. An advantage of the used scale of habitats is the sufficiently detailed catalogue which takes into account the habitats that have been highly influenced or created by human activities (in the catalogue - the $\mathrm{X}$ category) (Chytrý et al. 2001). The habitat point values served to represent graphically the development of the ecological values of individual habitats of the Sulkov site. The method applied was compared for example with the transfer of mapping classification units CORINE to degrees of ecological stability (Míchal, Löw 2003). The Hessian scoring methodology proved to facilitate a more detailed quantification of the ecological condition of habitats that the commonly used scale of ecological stability. 


\section{Results}

\section{Development of the area}

Based on the study of historical resources, a basic chronological overview of the development of the area in the Sulkov site was compiled (Table 1, Fig. 2). The individual stages of the development were limited on the basis of significant changes in the development of the area utility. Out of the mentioned sites, we can mark the ecotope 2 as the site decisive in determining the main stages. Naming the stages follows from the terminology used in the development of European landscapes (Vos, Meekes 1999, Antrop 2005). Due to the specific conditions of socio-historical development of the Czech territory and then taking into account the unique development of the studied area it is clear that the chronology of the development differs from other landscape studies of western or southern Europe (Antrop 2005, Jongman 2002). Definition of post-industrial landscape in the studied area follows from the study of post-industrial landscapes of the Czech Republic (Kolejka, Klimánek 2012).

The natural landscape of the area contained forest communities differentiated according to the habitat conditions. The natural woodland was of course subject to natural changes related to the climatic development in the Holocene. The beginning of the creation of the cultural landscape in the Pilsen area was in the Atlantic period (6000-4000 B.C.) according to archaeological research. The Sulkov site is in the shallow basin of the Luční brook at the place of its confluence with a small left-hand tributary. A more significant use of the studied area is connected with the Middle Ages development of Pilsen settlement. The foundation of Pilsen in 1295 was an event important for the development of the area. Pilsen was founded as a dominating residential centre of the Western Bohemia region. The economic use of the landscape in the studied area west of Pilsen was determined by the Premonstratensian monastery in Chotěšov founded in 1202-1210 (Hataj 1927). The monastery was important in the development of fish-farming in the Luční brook basin. The first written mention of the pond in the area of Líní and Sulkov appears in the Kladruby Charta (the $13^{\text {th }}$ century) dated in 1115 (Svobodová 2000). The Sulkov Pond which existed in the period between the Middle Ages till 1868 probably belonged among the oldest ponds in the Czech lands. Its area was 47 ha which made it highly prosperous from the fish-farming views. An interesting fact is the production of reed mats which were exported to Bavaria together with fish production (Hataj 1926). The Lažikov Pond (Radschiner Teich) was founded down the stream in the vicinity of the Sulkov Pond dam in the $14^{\text {th }}$ century. It was drained in 1850.

The traditional landscape started being dramatically changed to industrial landscape caused by subsurface hard coal mining, coal processing and the development of heavy industry. The coal seams were first opened randomly using primi-

Table 1. Stages of ecotope development in the Sulkov site.

\begin{tabular}{|c|c|c|c|c|c|c|}
\hline $\begin{array}{c}\text { Stages of landscape } \\
\text { development }\end{array}$ & Period & Ecotope 1 & Ecotope 2 & Ecotope 3 & Ecotope 4 & Ecotope 5 \\
\hline 1 natural & Until Middle Ages & \multicolumn{5}{|c|}{ A forest of natural species composition with a brook } \\
\hline $\begin{array}{l}2 \text { traditional, } \\
\text { pre-industrial }\end{array}$ & $\begin{array}{c}\text { From Middle Ages } \\
\text { to the middle of the } \\
19^{\text {th }} \text { century }\end{array}$ & \multicolumn{5}{|l|}{ Pond } \\
\hline \multirow{3}{*}{3 industrial } & $\begin{array}{c}\text { Mid-19 } \\
\text { century-1920 } \\
\text { century }\end{array}$ & \multicolumn{3}{|l|}{ Mining area } & \multirow{6}{*}{$\begin{array}{l}\text { Succession of } \\
\text { the bottom of } \\
\text { the drained } \\
\text { pond of the } \\
\text { area }\end{array}$} & \multirow{4}{*}{$\begin{array}{l}\text { Succession of } \\
\text { the bottom of } \\
\text { the drained } \\
\text { pond of the } \\
\text { area }\end{array}$} \\
\hline & 1921-1970 & $\begin{array}{l}\text { Succession } \\
\text { area }\end{array}$ & Industrial & \multirow{5}{*}{$\begin{array}{l}\text { Succession } \\
\text { of area after } \\
\text { mining }\end{array}$} & & \\
\hline & 1971-1996 & $\begin{array}{l}\text { Tailings } \\
\text { pond }\end{array}$ & landfill & & & \\
\hline \multirow[b]{2}{*}{4 post-industrial } & 1997-2002 & \multirow{2}{*}{$\begin{array}{l}\text { Succession } \\
\text { on the tail- } \\
\text { ings pond } \\
\text { area }\end{array}$} & \multirow[b]{2}{*}{$\begin{array}{l}\text { Reclaimed } \\
\text { landfill }\end{array}$} & & & \\
\hline & 2003-2009 & & & & & \multirow{2}{*}{$\begin{array}{l}\text { Embank- } \\
\text { ment and } \\
\text { motorway }\end{array}$} \\
\hline 5 post-modern & 2010-2014 & Pond & Solar station & & & \\
\hline
\end{tabular}



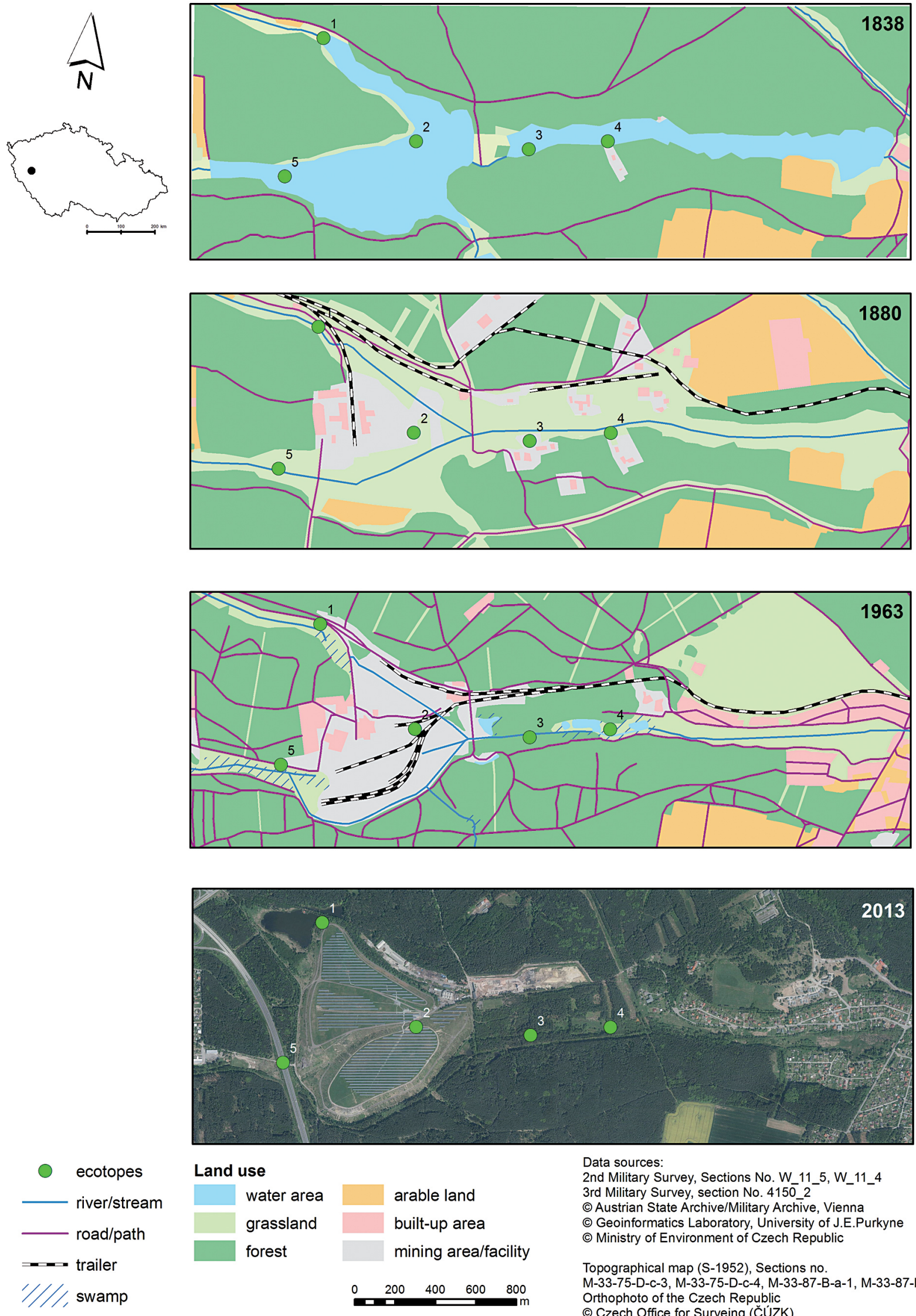

Data sources:

2nd Military Survey, Sections No. W 11_5, W_11_4

3rd Military Survey, section No. $415 \overline{0} 2$

(c) Austrian State Archive/Military Archive, Vienna

(c) Geoinformatics Laboratory, University of J.E.Purkyne

(c) Ministry of Environment of Czech Republic

Topographical map (S-1952), Sections no.

M-33-75-D-c-3, M-33-75-D-c-4, M-33-87-B-a-1, M-33-87-B-a-2

Orthophoto of the Czech Republic

(c) Czech Office for Surveing (ČÚZK)

Fig. 2. Land use development (1838-2013) and location of ecotopes in the Sulkov site. 
tive subsurface mines reaching as little as 30-40 metres down (Šlajer 1970). Due to the development of mining, the ponds in the Luční brook basin were gradually drained. Other wild-card reasons were used to drain the ponds, for example alleged participation of wetland areas around the ponds in the spread of malaria (Hataj 1926). Based on contracts, the land was supposed to be returned in the original condition after the mining ended, which should have enabled re-flooding. The modernisation of mining and continuous exploration enabled the development of coal mining in the Sulkov site. Mining in the Sulkov mine was initiated in 1872. With its depth of 252 metres, it was the deepest mine in the whole region of Western Bohemia (Svobodová et al. 2000). Thirty new coke production furnaces were opened in 1877 in Sulkov. In the western neighbourhood, mining was initiated in 1881 in the "Sulkovský pomocný" mine. The depth of its main pit was 485 metres (Svobodová 2000). Up to $200,000 \mathrm{t}$ of high-quality coal was mined, which was exported to Germany and Austria.

The development of hard-coal mining in the main mines of the studied site may be documented using the data of mine water pumping which had already started during the pit excavation (Table 2 ). The contaminated mine water of total flow of $159 \mathrm{dm}^{3} \mathrm{~s}^{-1}$ was conducted to the Luční Brook with an average natural flow of 148 $\mathrm{dm}^{3} \mathrm{~s}^{-1}$, which was thus converted into a waste sewer with disastrous consequences for the water quality (Soukup 1936). The Luční Brook bed was redirected to the souther edge of the mine to a position in which it can be found today. The influence of mine water chemistry typical for its low content of $\mathrm{pH}$, high content of iron, manganese, sulphates, etc. is still felt today in the quality of ground water and surface water. Undermining increased the ability of infiltration of precipitations. The mines in Sulkov (the Sulkov mine and "Sulkovský pomocný" mine) were closed down after a breakout of mining waters from the closed neighbouring mines Matylda and Marie (Švoma
1980). This event is related with flooding of the Luční Brook on January 13th 1920 (Svobodová 2000). Hard coal mining continued in the largest mines of the Pilsen Basin till the complete stop at the end of the 1990s.

The development of demand for workforce in the mines reflected significantly in the development of population. The development of settlement system around Pilsen was very specifically influenced by the development of the demand for workforce in the hard coal or kaolin mines. The foundation of the Sulkov settlement is directly connected with the foundation of the miners' colony. The Sulkov mines employed up to 1,700 people when at the top of mining. Daneš (1917) dealt with this Pilsen phenomenon in detail. In his study, he shows large differences in the development of population in individual settlements. The beginning of settlement development polarisation can be seen here which also influences indirectly the current suburbanisation processes (Kopp et al. 2013). The area, which was influenced most significantly by the development of hard coal and kaolin mining, mostly west and north of Pilsen, reached its greatest population growth between the second half of the $19^{\text {th }}$ century and the first quarter of the $20^{\text {th }}$ century. However, these suburban sectors currently show a lower level of environmental quality as well as a lower quality of housing thus becoming less attractive in the housing development (Kopp et al. 2013).

The development of the industrial landscape in the Sulkov site continued after the mining had been terminated. The mining premises connected to the railway by a spur was determined to be a spot suitable as a brownfield to store industrial waste from the Škoda Pilsen engineering company. Storing the waste started as early as the 1920s and various waste was stored in the landfill in the first stage (Charvát 1989). Even toxic materials might have entered the landfill. Any drilling exploration is no recommended as part of ammunition was dropped on the Pilsen landfill at

Table 2. Operation of mines and overview of pumped mine waters in the Sulkov site.

\begin{tabular}{|l|c|c|c|}
\hline \multicolumn{1}{|c|}{ Mine } & Start of pumping & End of pumping & Average pumping yield $\left(\mathrm{dm}^{-3} \mathrm{~s}^{-1}\right)$ \\
\hline Sulkovský & 1868 & 1921 & 59 \\
\hline Max-Karel & 1873 & 1902 & 10 \\
\hline Sulkovský pomocný & 1877 & 1920 & 90 \\
\hline
\end{tabular}


the end of the $2^{\text {nd }}$ World War during Pilsen bombardment. The acidic environment of the landfill might potentially cause a breach in the containers of toxic substances (Charvát 1989). Later on, the landfill served the Škoda company as a landfill of ash, slag, carbide sludge, steelworks sand, municipal waste, and partly also oil-contaminated soil (Charvát 1989). The main stage of waste disposal began in the early 1970s when the landfill was extended as far as the north-west part of the site (Fig. 3). The original mining objects and the mining colony were destroyed. The inhabitants were moved to the new part of Sulkov outside of the landfill site. Water management of the landfill used water from the Luční Brook, though almost no water was brought back to the recipient directly, only during one-off pumping of water from the lagoons etc. The contamination of ground and surface water occurred due to ash floating on the surface of the underground water and washing the dumps with rain water (Stočes 1967, Charvát 1989, 1990).

There was a decline in storing and transition to reclamation of waste heap in the 1990s. The shape the landfill was arranged, covered with soil, grassed over and partly planted with pine trees. The risk of underground water contamination is continuously monitored as according to a hydrogeological survey part of the underground water stream still runs through the original course of the brook, i.e. partly under the body of the dump (Charvát 1990). Another complication is represented by deserted and flooded mines under the body of the dump as undermining reaches under approximately a half of the landfill.

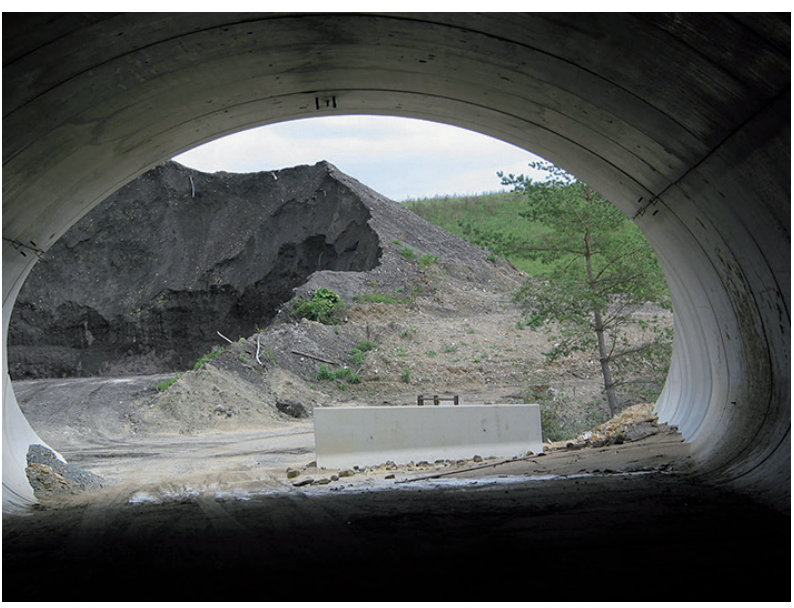

Fig. 3. The Sulkov landfill residue viewed from new motorway in 2002. Photo Jan Kopp.
In the post-communist era, the suburban landscape of Pilsen starts to develop due to the influence of residential and commercial suburbanisation processes. The Sulkov settlement is modernised by reconstruction of houses, new industrial sites appear as investments of German companies. The area is influenced by the construction of motorway bypass in the west edge which was put into operation at the end of 2003 (Kopp 2005). The traffic location near the motorway bypass is generally decisive in the location of new shops, services, or industrial production sites (Kopp et al. 2013).

Another important use of the Sulkov site reflects the tendency of the Czech Republic to provide governmental support to alternative energy resources within the commitments of the EU countries. The high guaranteed prices of solar electricity in particular led to the boom in their construction which culminated in 2010. The interest of great investors in constructions of new resources has dropped since January 2011 when the Czech Republic drastically decreased the guaranteed purchase price for newly connected sources over 100 kilowatts from CZE 12,150 to CZE 5,500 per megawatt-hour (ČTK 2010). By the end of 2011, solar power plants with the installed 1,959-megawatt performance were connected to the distribution network. This represents the performance of 185.4 watt per capita which places the Czech Republic to the third position after Germany and Italy (ČTK 2010).

In 2010, the operation of the $12^{\text {th }}$ largest solar power plant in the Czech Republic was initiated on the reclaimed slag heap in the Sulkov landfill. The power plant whose total installed performance is almost $10 \mathrm{MW}$ is divided into two parts, each with an installed performance of 4.99 MW. The panel cover an area of 51.5 ha; they are placed in rows in the east - west direction. They are the photovoltaic panels Sunmodule SW 215 with a fixed inclination of $32^{\circ}$ from the horizontal plane (Suncad 2014). The rows of panels are placed on the site of the former landfill on five areas separated by inner communications.

\section{Development of ecotopes}

The development of the selected ecotopes in the Sulkov site was differentiated according to the intensity of impact of main activities in the 
Sulkov site. The leading changes in the use of the site described in the previous text determined the development of the ecotope 2 . The ecotope 1 in the northern part of the site lies in a shallow valley of a tiny left-hand tributary of the Luční Brook. The ecotope 1 was part of one of two spits of the large area of the Sulkov Pond. Later on, a spot at the foot of the dump was left, which functioned temporarily as tailing pond of the waste water management. A small pond area for sport fishing has been reopened since 2010. The use of the ecotope 3 was intense until the termination of mining in 1920. Consequently, industrial waste was dropped here and the development of the ecotope is determined by the succession in slag heaps after the mining up to today's stage of grown forest cover of secondary tree composition. Unlike the rest, the ecotope 4 was only flooded up until 1850 by the Lažikov Pond. Mining works were in progress here (Max-Karel mine), but the ecotope was not directly in the mining site. Thus it developed through the succession of vegetation of the uncovered bottom of the former pond until the current stage of wetland area with the Luční Brook running through it and with marginal spread of self-seeded tree species (Fig. 4). The development of the ecotope 5 was specific through the fact that

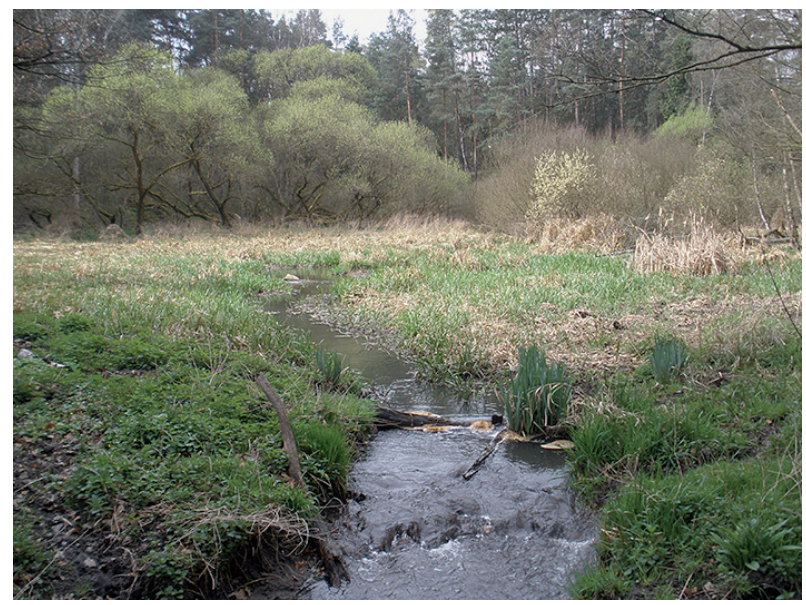

Fig. 4. Ecotope 4 - succession of vegetation of the uncovered bottom of the former pond with the Luční Brook in 2014. Photo Jan Kopp.

it had not been a direct part of mining sites, therefore it developed through succession processes on muddy substrate of the original bottom of the drained pond. The beginning of the $21^{\text {st }}$ century sees an embankment with a motorway bypass of Pilsen in the location of the ecotope 5.

Based on the table evaluation of ecotopes using the Hessian scoring methodology (Table 3), we illustrated the development of the ecotopes in the time evolution since the beginning of the $19^{\text {th }}$

Table 3. Development of ecotopes according to the category and point value of the ecological condition (in brackets).

\begin{tabular}{|c|c|c|c|c|c|c|}
\hline $\begin{array}{c}\text { Stages of landscape } \\
\text { development }\end{array}$ & Period & Ecotope 1 & Ecotope 2 & Ecotope 3 & Ecotope 4 & Ecotope 5 \\
\hline 1 natural & Until Middle Ages & \multicolumn{5}{|c|}{ Dry acidophilous oak forests (38) and Reed vegetation of brooks (33) } \\
\hline $\begin{array}{l}2 \text { traditional, } \\
\text { pre-industrial }\end{array}$ & $\begin{array}{l}\text { From Middle } \\
\text { Ages to the } \\
\text { middle of the 19th } \\
\text { century }\end{array}$ & \multicolumn{5}{|c|}{ Reed beds of eutrophic still waters (28) } \\
\hline \multirow{3}{*}{3 industrial } & $\begin{array}{l}\text { Mid. 19th centu- } \\
\text { ry-1920 }\end{array}$ & \multicolumn{3}{|c|}{$\begin{array}{l}\text { New mining areas and waste dumps (13) } \\
\text { and Fallow land in industrial sites (6) }\end{array}$} & \multirow{6}{*}{$\begin{array}{l}\text { Mezotrophic } \\
\text { vegetation of } \\
\text { muddy sub- } \\
\text { strata (36) }\end{array}$} & \multirow{4}{*}{$\begin{array}{l}\text { Mezotrophic } \\
\text { vegetation of } \\
\text { muddy sub- } \\
\text { strata (36) }\end{array}$} \\
\hline & 1921-1970 & $\begin{array}{l}\text { Vegetation } \\
\text { on aban- } \\
\text { doned de- } \\
\text { graded areas } \\
(10)\end{array}$ & \multirow[t]{2}{*}{$\begin{array}{l}\text { Industrial } \\
\text { waste dump } \\
(0)\end{array}$} & \multirow{5}{*}{$\begin{array}{l}\text { Vegetation } \\
\text { on aban- } \\
\text { doned de- } \\
\text { graded areas } \\
(10) \text { - } \\
\text { Degraded } \\
\text { forests (19) }\end{array}$} & & \\
\hline & 1971-1996 & $\begin{array}{l}\text { Tailing } \\
\text { ponds }(0)\end{array}$ & & & & \\
\hline \multirow[b]{2}{*}{4 post-industrial } & 1997-2002 & \multirow{2}{*}{$\begin{array}{l}\text { Waterlogged } \\
\text { ruderal } \\
\text { fallow land } \\
(19)\end{array}$} & \multirow{2}{*}{$\begin{array}{l}\text { Vegetation } \\
\text { on aban- } \\
\text { doned de- } \\
\text { graded areas }\end{array}$} & & & \\
\hline & 2003-2009 & & & & & \multirow{2}{*}{$\begin{array}{l}\text { Impervious } \\
\text { surfaces }(0)\end{array}$} \\
\hline 5 post-modern & 2010-2014 & $\begin{array}{l}\text { Vegetation } \\
\text { in new water } \\
\text { areas }(16)\end{array}$ & $\begin{array}{l}\text { Fallow land } \\
\text { in industrial } \\
\text { sites (6) }\end{array}$ & & & \\
\hline
\end{tabular}

Source: own processing, categories according to Chytrý at al. (2001), point values according to Seják (2005). 


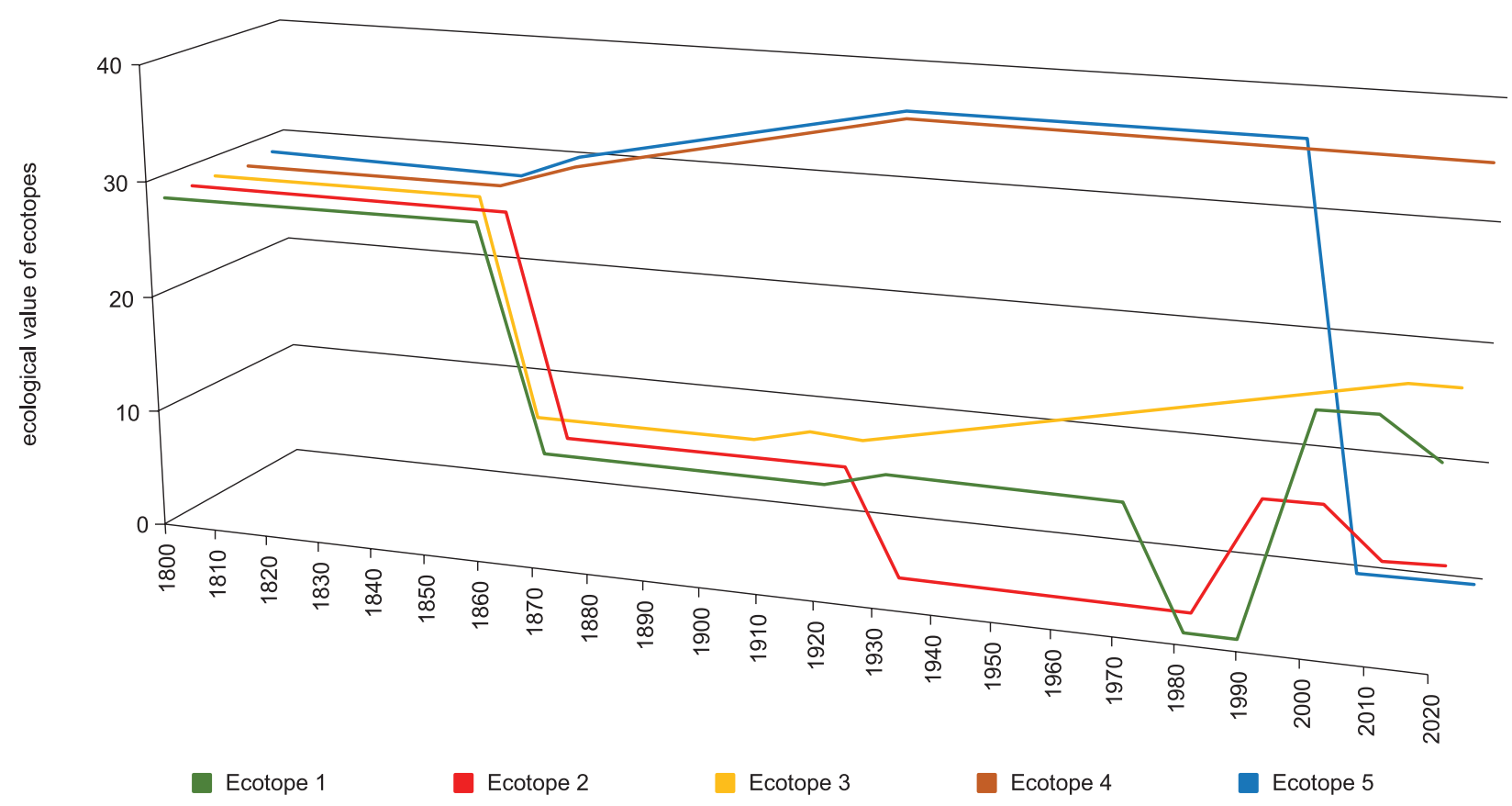

Fig. 5. Development of ecological value of ecotopes in the Sulkov site.

Source: own processing, point values of habitats according to the Hessian scoring methodology (Seják 2005, Seják et al. 2011).

century (Fig. 5). The curves of the development were constructed so that they illustrate a realistic course of changes of ecological values of the ecotopes. There are step changes, e.g. a pond drainage and setting up a mining site, other changes are gradual, especially the succession of unused areas.

The graph of ecological value of ecotopes shows different trajectories of development whereas it is possible to follow two facts. The essential differentiation occurred during the pond drainage and the launch of mining in ecotopes 1 , 2 and 3. In the period after 1990, an increase in the process of differentiation of the individual ecotopes occurs from the view of the ecological value as a result of new uses of suburban landscape (motorway, solar power plant, fishing pond).

\section{Discussion}

The studied Sulkov site serves as an example of significant changes in the use of the natural potential of a location in the western part of the suburban landscape of Pilsen. The presented development since the $19^{\text {th }}$ century documents some typical features of the suburban landscape, specifically its developmental dynamics and the heterogeneity of the vegetation cover of areas from natural habitats through habitats significantly influenced by human activities. The landscape exploitation in the model site was gradually concentrated on (1) the use of water potential of the shallow valley of the Luční Brook (used since Middle Ages as fish ponds), (2) quality hard coal mining, (3) industrial waste storage, (4) the use of solar energy potential. The functions of the suburban landscape are mainly related to the waste storage as a specific municipal need with which it burdens the surrounding landscape. The hard coal mining helped accelerate the settlement and industrial development of the agglomeration of Pilsen. The use of the area in fish-farming or solar energy is not related to the position in the suburban landscape but with the economic needs and technological possibilities in individual stages of the social development. The suburban landscape in the studied area was mono-functional in history. The dominant use of the landscape in individual stages influenced the whole site including the development of the nearby settlement. On the one hand, the stage of coal mining was important with respect to the need of workforce and foundation of the settlement of Sulkov as a mining colony. However, on the other hand, the greatly decreased quality of the environment predetermined the further use of the area as a landfill. The poor quality of the environment decreased the attractiveness of the site for the development of residential suburbanisation developing since the 
end of the $19^{\text {th }}$ century in the landscape-ecologically more valuable parts of the suburban landscape of Pilsen (Kopp et al. 2013).

Seen in detail, the whole area of the site was not utilised with the same intensity. As shown in the comparison of the selected ecotopes, the evolution was differentiated and some ecotopes evolved outside the direct influence of human activities, in a natural way. Thus in terms of internal differentiation of the site, we can speak of a jumbled mosaic of ecotopes of various intensities of human use typical for suburban landscapes (Antrop, Eetvelde 2000). A certain decrease of anthropogenic degradation of the landscape in the current stage where it is dominated by a solar power plant led to an additional strengthening of the recreational function setting up a fishing pond. The fragmentation is doubtlessly fragmented (Jongman 2002) as a result of closing and fencing of the solar plant, as a consequence of a new motorway, as well as the existence of residual heaps and water areas in the locations of falling ground after underground mining.

In the context of the European landscape evolution, the model site is highly industrial in character complemented by other features (Vos, Meekes 1999, Table 4). In the regional context of a suburban landscape with suburban forests, residential and commercial suburbanisation as well as an important agricultural function we can speak of a multifunctional landscape (Degórski 2003). In the Sulkov site in the current stage of evolution, elements of marginalized vanishing landscapes can be found (Table 4). The current research also uses the term energy landscape for the landscapes significantly influenced by energy acquisition (Pasqualettia, Brown 2014). The development of the Sulkov site belongs to this category with respect to original coal mining and current solar power plant operation. The solar power plant may be considered a sign of a certain, probably temporary, homogenisation of the Czech landscape. European landscape homoge- nisation is mostly the result of global economics (Jongman 2002).

The documented historical development of the Sulkov site proved that significant changes in the use of natural potential were determined by social and economic demand in individual stages of the development. The social-economic demand as an essential driving force was determined on the state (national) level and further influenced by European trends. This conclusion is in accord with the general suppositions of the driving forces of evolution (Antrop 2005) and other model studies of European landscape evolution (Balej et al. 2008, Martinát et al. 2014). The particular type of use of an area was then co-decided by the natural potential of the area the the geographic location with a good accessibility, i.e. local and regional factors.

The study showed an important chain bond between the individual stages of evolution of area use:

a) the demand for coal mining caused the drainage of ponds,

b) the location of the industrial dump was decided by the existence of "brownfield" in the form of a deserted mining site and by connecting the site to the railway,

c) the reclaimed dump heap provided a suitable area for the construction of a solar power plant.

However, the detailed evolution of individual ecotopes was very different. The originally insignificant deviations in the natural potential led as a consequence to a significantly different ecological condition of the ecotopes. For example, no or less intense coal mining in ecotopes 4 and 3 resulted in the locations not being further used to waste storage and their current character is more natural. While the succession evolution of some ecotopes is a long-term affair, there are step changes in the human use of sites. The social-economic requirements on the use of an area reflect not only the regional development (the de-

Table 4. Landscape types according to different intensities of man's control (acc. to Vos, Meekes 1999).

\begin{tabular}{|c|l|l|l|}
\hline Type & \multicolumn{1}{|c|}{ Landscape character } & \multicolumn{1}{|c|}{ Landscape type } & $\begin{array}{c}\text { Intensity of man's } \\
\text { control }\end{array}$ \\
\hline 1 & Industrial production landscapes & Landscape as an industry & Very high \\
\hline 2 & Overstressed multifunctional landscapes & Landscape as a supermarket & High \\
\hline 3 & Archaic traditional landscapes & Landscape as a historical museum & Medium \\
\hline 4 & Marginalized vanishing landscapes & Landscape as a ruin & Low \\
\hline 5 & Natural relict landscapes & Landscape as a wilderness & Very low \\
\hline
\end{tabular}


velopment of industrial and settlement agglomeration of Pilsen) but recently also global tendencies (support of alternative energy resources). Sudden changes in the use may be influenced by natural risk processes, as was shown in our model area in the form of a flood on the Luční Brook in 1920, which was one of the factors influencing the termination of hard coal mining.

Our study in the scale from decades to centuries can prove the driving forces of the landscape evolution following the concept of "keystone processes" (Marcucci 2000) in the categories of cultural processes (economic activity, political land control), disturbances (floods, mining, highway construction) and colonization patterns.

\section{Conclusion}

In terms of strategic planning, this study documents using a concrete example that the evolution of an area is determined by driving forces following from commonly unpredictable changes in the social requirements. The planning and regional policy as a key factor of the evolution of European landscape (Jongman 2002) did not prove to be a decisive driving force in the studied area. While the pond system on the Luční Brook organised by the Chotěšov monastery was an example of a planned use of landscape, the further development shows a rather unplanned sequence of changes in the use of the landscape heading towards entropy (Antrop 1998). At the beginning of the mining, subsequent renewal of ponds after termination of the mining was supposed. Problems with water management of the mines together with the flood of the Luční Brook terminated the mining which stopped being lucrative as well as with respect to the growing competition of modern mines. However, the area started to be used as an industrial dump almost immediately. Historical resources mention both the originally random hard coal mining and unregulated waste dumping in the first stages of the landfill. The social-economic changes in the Czech Republic at the beginning of the 1990s led to a decline in heavy industry in Pilsen, and therefore also a controlled termination of landfill. This planned process culminated in the reclamation of the landfill body. However, the boom of solar power plants constructions influenced by the global trends in power industry as well as a result of exaggerated financial support provided by the government presents a new unexpected use of the area. The land use plan of the Líně municipality where the Sulkov site belongs is changed. The change of the use of the area is permitted for the limited period of 25 years (Hucl 2010). There are probably no ideas of any further use of the area. The strategic planning of the development thus was not historically determining. The example of the Sulkov site shows that the evolution proceeds under the influence of social-economic interests whose changes are usually unpredictable. The strategic planning of the use of landscape should concentrate on alternative forecasting of a further development and propose not only one-direction plans but also variable scenarios of future development. Such scenarios can be partly assembled as a chain of logically successive stages, unless possible global, national and regional social-economic changes are well forecast.

\section{Acknowledgments}

This article includes result generated by project of the Technology Agency of the Czech Republic OMEGA TD020323 Strategic planning of municipalities, cities and regions: appeals, problems and possibilities of solutions and by project QJ1220233 NAZV MZe ČR Assesment of agricultural land in the areas of extinct fish pond systems with the aim of supporting sustainable management of water and soil resources in the Czech Republic.

\section{References}

Antrop M., 1998. Landscape change: Plan or chaos? Landscape and Urban Planning 41: 155- 161. DOI: 10.1016/ S0169-2046(98)00068-1.

Antrop M., 2004. Landscape change and the urbanization process in Europe. Landscape and Urban Planning 67: 9-26. DOI: 10.1016/S0169-2046(03)00026-4

Antrop M., 2005. Why landscapes of the past are important for the future. Landscape and Urban Planning 70: 21-34. DOI: 10.1016/j.landurbplan.2003.10.002.

Antrop M., Eetvelde V. V., 2000. Holistic aspects of suburban landscapes: visual image interpretation and landscape metrics. Landscape and Urban Planning 50: 43-58. DOI: 10.1016/S0169-2046(00)00079-7.

Balej M., Anděl J., Oršulák T., Raška P., 2008. Vývoj environmentálního stresu v severozápadní části Česka: nové prrístupy a metody (Development of environmental stress in the northwest part of Czechia: new approaches and methods). Geografie 113(3): 320-336. 
Baštová M., Dokoupil J. 2010. Negativní dopady př́mých zahraničních investic na trh práce města Plzně (The negative impact of direct foreign investment on the labour market of the city of Pilsen). Geografie 115(2): 188-206.

Bräuer I., 2003. Money as an indicator: to make use of economic evaluation for biodiversity conservation. Agriculture, Ecosystems and Environment 98: 483-491. DOI: 10.1016/S0167-8809(03)00107-5.

Bürgi M., Hersperger A. M., Schneeberger N., 2004. Driving forces of landscape change: current and new directions. Landscape Ecology 19: 857-868. DOI: 10.1007/s10980-0040245-8.

Charvát T. (ed.), 1989. Sulkov - závěrečné vyhodnocení hydrogeologického prüzkumu (Sulkov - final assessment of the hydrogeological survey) Research report. Vodní zdroje, Praha.

Charvát T. (ed.), 1990. Sulkov - výsledky režimních odběrů vzorků podzemní vody za období červenec 1989 až červen 1990 (Sulkov - results of the regime sampling of underground water for the period July 1989 to June 1990) Research report. Vodní zdroje, Praha.

Chytrý M., Kučera T., Kočí M. (eds.), 2001. Katalog biotopů České republiky (Catalogue of habitats of the Czech Republic). AOPK ČR, Praha.

ČTK, 2010. Energetický regulační úřad sníží výkupní ceny elektřiny z fotovoltaiky o 50 procent (The Energy regulatory authority will reduce the purchase price of electricity from photovoltaics by 50 per cent). Online: http://zpravy.e15.cz/byznys/prumysl-a-energetika/eru-snizi-vykupni-ceny-elektriny-z-fotovoltaiky-o-50-procent (accessed 10 May 2014).

Daneš J. V., 1917. Obyvatelstvo království Českého v letech 1843-1910. Oblast plzeňská (Population of the Czech Kingdom in the years 1843-1910. Pilsen region). Národopisný věstník českoslovanský (Společnost národopisného musea českoslovanského) 12(3): 296 - 318.

Degórski M., 2003. Some Aspects of Multifunctional Landscape Character in the Interdisciplinary Environmental Study. In: Helming K., Wiggering, H. (eds), Sustainable Development of Multifunctional Landscapes. Springer -Verlag, Berlin: 53-65.

Ehrenfeld J. G., 2000. Evaluating wetlands within an urban context. Ecological Engineering 15: 253-265. DOI: 10.1016/ S0925-8574(00)00080-X.

Forman R.T.T., 1998. Landscape ecology, the growing foundation in land-use planning and natural-resource management. In: Kovář P. (ed.), Nature and culture in landscape ecology: experiences for the $3^{\text {rd }}$ millenium. CZ - IALE, Praha: 13-21.

Forman R.T.T., Godron M., 1986. Landscape Ecology. John Wiley and Sons, Inc., New York.

Głębocki B., Perdał R., 2013. Transactions in land in the suburban zone of Bydgoszcz over the years 2007-2010. Quaestiones Geographicae 32(4): 103-116. DOI 10.2478/ quageo-2013-0037, ISSN 0137-477X.

Hataj V., 1926. Rybníky na bývalém panství chotěšovském (Ponds in the former Chotěšov domain). Plzeňsko: list pro vlastivědu západních Čech 5: 84-87.

Hataj V., 1927. Chotěšov: část prvá (Chotěšov: Part One). Památná místa našeho kraje 7. Národopisné museum, Plzeň: 1-26.

Heilig G. K., 2003. Multifunctionality of Landscapes and Ecosytem Services with Respect to Rural Development. In: Helming, K., Wiggering, H. (eds), Sustainable Devel- opment of Multifunctional Landscapes. Springer -Verlag, Berlin: 39-51.

Hucl V., 2010. Změna územního plánu obce Líně (Change in the land use plan of the Líně municipality). Online: http:// geoportal.plzensky-kraj.cz/gs/uzemni-plany-a-dalsi-nastroje-uzemniho-planovani (accessed 12 May 2014).

Jongman R. H. G., 2002. Homogenisation and fragmentation of the European landscape: ecological consequences and solutions Landscape and Urban Planning 58: 211-221 DOI: 10.1016/S0169-2046(01)00222-5.

Kolejka J., Klimánek M., 2012. Typologie a vymezení postindustriální krajiny Česka (Typology and definition of Czech post-industrial landscape). Geografie 117(3): 289307.

Kopp J., 2004. Ekohydrologické hodnocení povodí v př́městské krajině - př́padová studie povodí Lučního potoka (Eco-hydrological assessment of basins in the suburban landscape - case study of the Luční Brook Basin) PhD thesis. Univerzita Karlova v Praze, Praha.

Kopp J., 2005. Případová studie ekohydrologického vlivu dálnice D5 na povodí Lučního potoka (A case study of eco-hydrological influence of the D5 motorway on the Luční Brook Basin). Miscellanea geographica Universitatis Bohemie Occidentalis 11: 149-157.

Kopp J., 2012. Ekohydrologické důsledky rozvoje př́íměstské krajiny v Česku (Ecohydrological consequences of suburban landscape development in Czechia). In: Koutský J., Raška P. (eds), Výzkum regionálního rozvoje - vybrané prístupy a témata. Univerzita J.E. Purkyně, Ustí nad Labem: 157-175.

Kopp J., Novotná M., Matušková A., 2013. Rezidenční suburbanizace $\mathrm{v}$ plzeňském městském regionu v krajinně-ekologickém kontextu (Residential suburbanisation in the Pilsen urban region in the landscape-ecological context). In: Ouředníček M., Špačková P., Novák J. (eds), Sub urbs: krajina, sídla a lidé. Academia, Praha: 150-174.

Kovář P., 1995. Is plant community organization level relevant to monitoring landsacpe heterogeneity? Two case studies of mosic landscapes in the suburban zones of Prague, Czech Republic. Landscape and Urban Planning 32: 137-151.

McQuillan D. A., 2010. The interface of physical and historical geography: the analysis of farming decisions in response to drought hazards on the margins of the Great Plains. In: Baker A. R. H., Billinge M. (eds), Period and Place: Research Methods in Historical Geography. Cambridge Studies in Historical Geography 1, Cambridge University Press, Cambridge: 136-144.

Létal A., Smolová I., Szczyrba Z., 2001. Transformace př́iměstské krajiny (Transformation of suburban landscape). Urbanismus a územní rozvoj 4(4): 15-21.

Löw J., Míchal I., 2003. Krajinný ráz (Landscape character). Lesnická práce, Kostelec nad Černými lesy.

Marcucci D. J., 2000. Landscape history as a planning tool. Landscape and Urban Planning 49: 67-81. DOI: 10.1016/ S0169-2046(00)00054-2.

Markuszewska I., 2013. Changes of agricultural landscape pattern - non-natural driving forces analyzing based on the North-Western Region of Poland. Quaestiones Geographicae 32(1): 5-14. DOI 10.2478/quageo-2013-0001, ISSN 0137-477X.

Martinát S., Dvořák P., Klusáček P., Kunc J., Havlíček M., Hybné síly dlouhodobých proměn industrializované krajiny (př́padová studie Hrušov) (Driving forces of 
long-term changes of industrialized landscape (case study of Hrušov)). Acta Pruhoniciana 106: 35-44.

Mulíček O., Olšová I., 2002. Město Brno a důsledky různých forem urbanizace (The city of Brno and consequences of various forms of urbanisation). Urbanismus a územní rozvoj 4(6): 17-21.

Naveh Z., 2001. Ten major premises for a holistic conception of multifunctional landscapes. Landscape and Urban Planning 57: 269-284 DOI: 10.1016/S0169-2046(01)00209-2.

Ouředníček M., 2007. Differential Suburban Development in the Prague Urban Region. Geografiska Annaler. Human Geography 89B(2): 111-125. DOI: 10.1111/j.14680467.2007.00243.x

Pasqualettia M. J., Brown M. A., 2014. Ancient discipline, modern concern: Geographers in the field of energy and society. Energy Research \& Social Science 1: 122-133. DOI: 10.1016/j.erss.2014.03.016.

Schneeberger N., Bürgi M., Hersperger A. M., Ewald K. C., 2007. Driving forces rates of landscape change as a promising combination for landscape change research-An application on the northern fringe of the Swiss Alps. Land Use Policy 24: 349-361. DOI: 10.1016/j.landusepol.2006.04.003.

Seják J. et al., 2011. Valuing Ecosystem Functions and Services in the Czech Republic Synthesis of the Key Findings. Project of the Czech Ministry of the Environment SP/2d3/99/07 Faculty of Environment, J. E. Purkyne University in Usti nad Labem.

Seják J., 2005. Základy udržitelné ekonomie př́rodních zdrojů a životního prostrééi (Fundamentals of sustainable economy of natural resources and the environment). Univerzita Jana Evangelisty Purkyně, Ústí nad Labem.

Soukup R., 1936. Úprava Lučního potoka a hospodáršé vodní nádrže v obci Lině (Modification of the Luční Brook and the farm pond in the Líně municipality) Approval report. Ing. R. Soukup, Praha.

Spilková J., Šefrna L., 2010. Uncoordinated new retail development and its impact on land use and soils: A pilot study on the urban fringe of Prague, Czech Republic. Landscape and Urban Planning 94: 141-148. DOI: 10.1016/j. landurbplan.2009.09.001.

Stočes I., 1977. Die hydrogeologischen Verhältnisse in verlassenen Bergbauwerken des Pilsner Steinkohlenbeckens. Folia Mus. Rer. natur. Bohemiae occidentalis, Geologica 9, Západočeské muzeum, Plzeň: 1-22.

Suncad, 2014. Fotovoltaická elektrárna Sulkov - Plzeň (Photovoltaic power plant Sulkov - Plzeň). Suncad s.r.o., Praha. Online: http://www.suncad.cz/suncad/cz/reference/ prumyslove-stavby/fotovoltaicka-elektrarna-sulkov-plzen-10-mwp-\%282x5mwp\%29-.140/ (accessed 25 May 2014).

Svobodová H. (ed.), 2000. O minulosti Liní v roce 2000: čtení z kronik a vzpominek pamětnikư (On the past of Líně in 2000: reading from chronicles and memoirs of witnesses). Vydavatelství Václav Kuna, Plzeň.

Šlajer J., 1970. Základní tendence vývoje uhelného průmyslu Plzeňska do roku 1890 (Fundamental tendencies in the development of coal mining industry of the Pilsen region until 1890). Minulostí Západočeského kraje 7: 65-86.

Švoma J., 1980. Hydrogeologické poměry plzeňské karbonské pánve (Hydrogeological conditions of the Pilsen carboniferous basin). Sborník geologických věd - hydrogeologie, inženýrská geologie 14: 83-107.

Sýkora L. (ed.), 2002. Suburbanizace a její sociální, ekonomické a ekologické důsledky (Suburbanisation and its social, economic and ecological consequences). Ústav pro ekopolitiku, Praha.

Valk A. van der, 2002. The Dutch planning experience. Landscape and Urban Planning 58: 201-210. DOI: 10.1016/ S0169-2046(01)00221-3.

Vos V., Meekes H., 1999. Trends in European cultural landscape development: perspectives for a sustainable future. Landscape and Urban Planning 46: 3-14. DOI: 10.1016/ S0169-2046(99)00043-2.

Vyskočil A., 2012. The tale of the landscape in the Czech lands in the 19th century. Historická geografie 38(1): 119-142. 